The book is written in a chatty style with frequent reference to Nobel prizes and more photographs of geneticists than of genetic phenomena. In leaning over backwards to try to avoid making intellectual demands on its potential student readership the book overbalanced into a whirlpool of incoherence. Good general textbooks in genetics are rare and this book does nothing to increase the frequency.

K. J. R. EDWARds

Department of Genetics, University of Cambridge

\title{
LYSENKOISM AND MOLECULAR GENETICS
}

AUTUMNIZATION AND ITS GENETIC INTERPRETATION. S. Rajki. Akadēmiai Kiadō, Budapest. 1967. Pp. 88. E1, 10 s.

In view of the apparent rejection of Lysenkoist doctrines in Russia and the acceptance of "Western" genetics, it is surprising to receive from behind the "Iron Curtain" an English version of "Autumnization and its genetic interpretation ". This is issued by the Publishing House of the Hungarian Academy of Sciences which suggests official approval.

The book describes some experiments which are claimed to demonstrate the autumnization of certain varieties of spring wheat, that is their conversion into winter-hardy, vernalisation-requiring forms by exposure to winter conditions. Although it is claimed that the initial material used in these experiments were pure lines, the change in the character of the lines was associated with severe winter killing which at least suggests that selection cannot be ruled out. Such claims for conversion into winter forms have of course been made before and this latest contribution is unlikely to convince any sceptics.

But the novel and most remarkable part of the book is the final section in which the author attempts to describe autumnization in terms of molecular biology. It consists of an attack on what is called " Crick's central dogma ", by which Rajki apparently means the self-duplicating properties of DNA and the genetic code. It is difficult to take this seriously because there is no evidence presented and the argument is very near to a "vital force" hypothesis being full of such undefined phrases as "life condition".

Perhaps this review should appear in a fiction column: but good fiction is at least convincing.

\author{
K. J. R. EDWARDS \\ Department of Genetics, University of Cambridge
}

\section{BIOCHEMICAL POLYMORPHISMS}

POLYMORPHISMES BIOCHIMIQUES DES ANIMAUX. Xth European Conference on Animal Blood Groups and Biochemical Polymorphisms, Paris 1966. Pp. 544. Published by the Institut National de la Recherche Agronomique, Paris 1967.

A meeting on biochemical polymorphisms in animals was held in Paris in 1966, jointly organised by the European Society for Blood Group Research, the Pasteur Institute of Paris, and the National Institute for Agricultural 